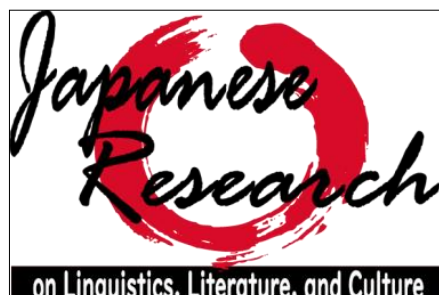

Japanese Research on Linguistics, Literature, and Culture Vol. 1 No. 1 Nov. 2018, Hal. 28-47, ISSN: 2655-4836

https://publikasi.dinus.ac.id/index.php/irllc/article/view/2097/1380

Published by Universitas Dian Nuswantoro,

Jl. Imam Bonjol 207, Semarang

\title{
Pemerian Alam Sebagai Simbol Femininitas

\author{
dalam Novel Hana wo Hakobu Imouto
}

\author{
Wawat Rahwati \\ Universitas Nasional \\ wawat.rahwati@yahoo.com
}

Article History: Submitted date 2018-11-08; Accepted date 2018-11-28; Published date 2018-11-28

\begin{abstract}
This paper discusses about interconnecting nature and women in one of Japanese literary work named Hana wo Hakobu Imouto written by Natsuki Ikezawa. He has written numerous novels and through his works such as Hana wo Hakobu Imouto, he depicts upon the relationship between nature and women. Through this novel I assume nature can be seen as a representation about femininity and has interconnection with women. According to my assumption, I analyze this novel by employing the cultural eco-feminism perspective to aim at showing how nature can be represented as a symbol of femininity through portraying the women characters and the setting of place of the story in this novel. The result is found that the water and earth as nature elements which have been portrayed dominantly in every setting of places in the story. The water is represented across by river in Paris, rain in Thailand, and sea in Bali show a symbol as a 'mother's womb called fetus which is very important to protect for someone's life. Meanwhile the earth is representing through rice fields show a symbol as a 'mother's earth called 'Gaia' who give a life by fruit, tree, and another natural resource for living thing who live on the earth. The illustrating of water as a 'mother's womb' and earth as 'a mother's earth can be inferred that those natural elements are symbols of femininity which represent of mother's nurture who protect someone's life.
\end{abstract}

Keyword: cultural eco-feminism, femininity, Hana wo Hakobu Imouto, nature 


\begin{abstract}
ABSTRAK
Penelitian ini membahas simbol femininitas melalui pemerian alam dalam sebuah novel Jepang yang berjudul Hana wo Hakobu Imouto karya Ikezawa Natsuki. Novel ini menceritakan interaksi perempuan dengan alam yang tampak dominan digambarkan dalam novel tersebut. Menurut pengamatan saya, pemerian unsur alam di setiap latar tempat terkesan mengacu pada simbol tertentu yang berkaitan dengan wacana femininitas. Berdasarkan asumsi tersebut, saya melakukan penelitian terhadap novel ini dengan mengaplikasikan teori ekofeminisme kultural untuk melihat bagaimana alam merepresentasikan simbol femininitas melalui pembahasan karakter tokoh dan latar tempat dalam cerita. Hasil penelitian menunjukkan bahwa terdapat dua unsur alam, yakni air dan tanah yang mendominasi setiap latar tempat dalam novel ini. Unsur air direpresentasikan sebagai 'rahim ibu' yang disebut fetus melalui penggambaran latar sungai di Paris, hujan di Thailand, dan latar laut di Bali. Unsur air juga digambarkan memiliki keterkaitan dengan perempuan melalui pembenaman tubuh Kaoru ke dalam laut. Melalui interkoneksi di antara keduanya, air dapat direpresentasikan sebagai unsur yang berperan penting dalam proses revitalisasi diri Kaoru yang melahirkan spirit dan kepercayaan dalam menghadapi opresi dari masyarakat patriarki. Selanjutnya unsur 'tanah' direpresentasikan sebagai simbol 'Ibu bumi' yang dikenal sebagai 'Gaia' melalui penggambaran latar sawah, hutan yang ada di Vietnam. Dari pemerian unsur air sebagai 'rahim ibu' dan unsur tanah sebagai 'ibu bumi' dapat disimpulkan bahwa kedua unsur alam tersebut merepresentasikan simbol femininitas perempuan yang merawat, melindungi, dan memberi hidup kepada semua makhluk di atas muka bumi ini.
\end{abstract}

Keyword: ekofeminis kultural, femininitas, Hana wo Hakobu Imouto, alam

\title{
1. Pendahuluan
}

Novel Hana wo Hakobu Imouto yang selanjutnya disebut dengan $\mathrm{HwHI}$ merupakan salah satu novel karya Ikezawa Natsuki, salah seorang sastrawan Jepang yang aktif menghasilkan karya baik dalam bentuk novel maupun puisi. Beberapa karyanya seperti novel Still Alive dan $\mathrm{HwHI}$ mendapatkan penghargaan. Novel Still Alive, ia mendapat penghargaan Akutagawa dan novel HwHI mendapat penghargaan Mainichi Shuppan Bunsho. Bahkan oleh Numano (2005), seorang pengamat sastra, Ikezawa Natsuki dianggap sebagai pengarang yang memiliki pandangan luas. Hal ini dapat dilihat melalui karya-karyanya yang tidak hanya menampilkan Jepang sebagai latar cerita, tetapi juga berbagai tempat yang ada di Asia berhasil diangkat menjadi latar yang dominan dalam ceritanya. Karena itu, ia menjadi seorang pengarang yang 
karya-karyanya banyak dibaca oleh orang asing, terutama para pembaca dari Asia. Salah satu novel Ikezawa yang menampilkan latar Asia adalah novel $\mathrm{HwHI}$ yang terbit pada tahun 2000 dan telah diterjemahkan ke dalam bahasa Inggris dengan judul A Burden of Flower .

$\mathrm{HwHI}$ menceritakan seorang tokoh perempuan bernama Kaoru Nishijima yang melakukan perjalanan ke Bali untuk menyelamatkan kakaknya yang bernama Tesuro Nishijima dari hukuman mati. Dalam novel diceritakan bahwa Tetsuro ditangkap di Bali atas tuduhan penyelundupan heroin sebanyak dua ratus gram. Tertangkapnya Tetsuro sebetulnya merupakan hasil jebakan dari salah seorang anggota mafia yang bekerja sama dengan oknum kepala polisi sektor Bali. Mereka berkomplot untuk menjebak orang-orang asing yang berada di Bali agar tergoda untuk membeli heroin dan menangkapnya pada saat mereka tengah asik menikmati heroin. Tujuan mereka melakukan skenario penangkapan orang asing adalah untuk menaikkan citra Kepala Polisi agar ia memperoleh kesempatan untuk dapat bekerja kembali di Jakarta.

Usaha Kaoru untuk menyelamatkan kakaknya dari hukuman mati tersebut, ternyata banyak mendapatkan kendala dari berbagai pihak. Kendala yang paling besar adalah dari para aparat pemerintahan dan sistem birokrasi setempat yang cenderung bersifat hierarkis. Kaoru harus menghadapi perlakuan diskriminatif dari aparat setempat, sehingga ia merasa tertekan dan enggan untuk tampil dihadapan publik. Bahkan saat wajahnya berkali-kali muncul di media massa dan mengaitkannya sebagai adik seorang pengedar heroin, ia menganggap seluruh masyarakat Bali memusuhinya, sehingga untuk sekadar makan di luar pun ia harus mengubah penampilannya. Dalam kondisi seperti ini, meskipun ia telah menyewa pengacara yang handal dan mampu berbahasa Indonesia, namun ia tetap merasa tidak akan mampu menolong kakaknya dengan memenangkan perkara Tetsuro di pengadilan. Akan tetapi, di tengah keputusasaannya, ia dihadapkan pada sebuah latar alam yang berupa laut di sebuah tempat bernama Uluwatu. Di tempat itu, alam seolah-olah memberi semangat dan rasa percaya diri pada Kaoru untuk bangkit dari masalah yang ia hadapi dan nalurinya pun berkata bahwa ia dapat memenangkan kasus kakaknya di pengadilan.

Selain tokoh Kaoru, dalam novel ini pun diceritakan beberapa tokoh perempuan, seperti tokoh Nguyen Ti An dan tokoh Inge Bruge. Nguyen Ti An adalah seorang perempuan Vietnam 
yang memiliki hubungan khusus dengan Tetsuro, sedangkan Inge Bruge adalah tokoh perempuan Eropa berkewarganegaraan Jerman. Tidak hanya Kaoru, kedua perempuan ini pun dalam novel $\mathrm{HwHI}$ masing-masing diceritakan memiliki keterkaitan dengan alam secara personal. Pada ketiga tokoh perempuan ini, alam seolah-olah berbicara dan berinteraksi dengan mereka. Tidak hanya itu, latar alam yang ditemui oleh tokoh-tokoh perempuan itu seakan memberikan kekuatan kepada tokoh-tokoh perempuan untuk menyelesaikan permasalahannya.

Sebagai mana halnya dengan novel-novel Ikezawa lainnya yang banyak menampilkan alam, dalam novel $H w H I$ pun unsur alam, seperti sungai, laut, hutan tampak begitu dominan digambarkan dan terkesan memiliki peran penting terhadap penyelesaian konflik-konfik yang terjadi, terutama konflik yang dihadapi oleh tokoh-tokoh perempuan yang muncul dalam novel tersebut. Hal yang menarik adalah unsur-unsur alam yang digambarkan dalam novel ini membangun hubungan secara spiritual dengan tokoh-tokoh perempuan, khususnya pada tokoh Kaoru. Bahkan Numano (2005) pun menyatakan bahwa novel ini banyak menampilkan unsurunsur seni, seperti lukisan, tarian, dan pahatan, sehingga novel ini dapat dikatakan sebagai geijutsu shosetsu (novel bersifat seni). Selain itu, menurutnya, dalam novel ini terdapat tema penting yang disampaikan oleh pengarang, yakni mengenai spirit air yang ada di Asia.

Unsur alam yang terkesan memiliki hubungan simbolik dengan perempuan, seakan menguatkan pandangan sebagian kaum ekofeminis, khususnya kelompok ekofeminis kultural yang meyakini bahwa antara perempuan dan alam tercipta sebuah hubungan khusus secara spiritual. Hubungan di antara mereka direpresentasikan melalui penggambaran unsur alam dengan karakter-karakter femininitas yang dimiliki oleh perempuan. Salah satu contohnya adalah hubungan alam dengan perempuan secara spiritual dikaitkan dengan mitos bumi sebagai sosok seorang 'ibu' dengan karakter-karakter femininnya, seperti 'melahirkan' dan memberi 'perawatan'. Bahkan Griffin, salah seorang tokoh ekofeminis menganggap bahwa perempuan merupakan bagian dari alam (Cox, 1998). Menurut pandangannya, perempuan adalah alam yang melihat alam, alam yang menangis, dan alam yang berbicara. Berdasarkan pandangan Griffin itu, dapat diasumisikan bahwa alam diasosiasikan mewakili karakter 
perempuan yang bersifat feminin, sehingga perempuan memiliki hubungan yang istimewa dengan alam.

\section{Kajian Teoretis}

Penelitian dalam karya sastra dengan menggunakan kajian ekofeminis relatif bukan sesuatu yang baru. Ada beberapa penelitian terdahulu, seperti penelitian oleh Ahmadi (2017) yang membahas "Feminitas, Ekofeminisme, dan Cerpen Indonesia" yang diterbitkan di Jurnal ilmiah bahasa dan kesusastraan Totobuang. Dalam penelitiannya Ahmadi yang menggunakan sumber data berupa kumpulan cerpen Kompas dari tahun 2012-2015, memperlihatkan bahwa ada kemunculan isu-isu feminitas melalui tindakan tokoh-tokoh perempuan, seperti perempuan yang mencintai tumbuhan, perempuan yang mengelola lingkungan, dan perempuan yang mencintai alam sekitar, seperti hujan, sungai (Ahmadi, 2017). Selanjutnya adalah tesis Lestari (2009) dengan judul Citra Wanita dalam Karya Sastra: Tinjauan Kritik Sastra Ekofeminis terhadap Kumpulan Cerpen Jiwaku adalah Wanita Karya Azimah Rahayu. Lestari menyatakan bahwa melalui pembahasan terhadap kumpulan cerpen itu ditemukan adanya kesadaran pada diri perempuan mengenai kodrat dan perannya sebagai perempuan dalam urusan domestik dan interaksinya dengan masyarakat sekitar, menjadi langkah tepat bagi perempuan untuk mensejajarkan kedudukannya dengan laki-laki (Lestari, 2009).

Dalam tulisan ini saya membahas novel $\mathrm{HwHI}$ untuk mendiskusikan keterkaitan perempuan dengan alam yang banyak digambarkan dalam novel ini. Permasalahan utama dalam penelitian ini adalah bagaimana alam direpresentasikan melalui hubungannya dengan tokoh-tokoh perempuan. Jika alam diasosiasikan memiliki karater yang bersifat feminin seperti yang dikatakan oleh Griffin, lantas bagaimana simbol femininitas itu direpresentasikan dalam novel HwHI ini. Untuk menjawab permasalahan tersebut, saya menggunakan kajian ekofeminisme dengan menekankankan pada konsep-konsep ekofeminis kultural untuk menemukan wacana-wacana dalam teks yang dapat merepresentasikan simbol-simbol femininitas dalam penggambaran unsur alam dalam novel $\mathrm{HwHI}$. 


\subsection{Ekofeminisme sebagai Perspektif dalam Penelitian Sastra.}

Ekofeminisme merupakan sebuah konsep pemikiran yang lahir dari berbagai gerakan feminis yang berupaya melindungi bumi dari kerusakan secara ekologi. Dilihat dari sejarahnya, istilah ini pertama digunakan oleh Fraicois d' Eaubonne pada tahun 1974 dalam bukunya yang berjudul Le Feminisme ou la Mort ia menyatakan bahwa ada keterkaitan langsung antara opresi perempuan dengan penindasan terhadap alam (Tong, 1998). Menurut King ada beberapa faktor yang melatarbelakangi terciptanya keterkaitan antara opresi perempuan dengan alam, yakni konsep dualisme dan pandangan hierarkis. Konsep dualisme dalam pandangan King ini merupakan konsep dari cara pandang terhadap pasangan yang berbeda bukan sesuatu yang saling melengkapi, namun diposisikan saling bertentangan. Pertentangan ini dapat dilihat dari adanya oposisi biner antara laki-laki versus perempuan (King, 1994).

Dalam pandangan dualisme, laki-laki dikaitkan dengan maskulinitas, pikiran, dan kekuasaan. Sebaliknya, perempuan cenderung dikaitkan dengan femininitas, tubuh, bumi, dan seksualitas. Di masyarakat patriarki, selain pandangan dualisme ini, berlaku pula nilai-nilai hierarki, yang menempatkan laki-laki lebih tinggi daripada perempuan dan perempuan lebih tinggi dari alam. Bertahtanya kedua konsep ini dalam masyarakat memunculkan praktik-praktik dominasi yang dilakukan oleh laki-laki terhadap perempuan dan juga alam. Praktik-praktik dominasi terhadap alam terlihat dalam bentuk penghancuran ekologi untuk kepentingan kapitalis dan industrialisasi. Bentuk-bentuk dominasi terhadap alam tersebut bagi kaum feminis secara tidak langsung akan memberi dampak buruk terhadap perempuan. Hal ini karena kaum perempuan merupakan sosok yang bertanggung jawab dalam penyediaan sumber pangan, sehingga untuk memenuhi kebutuhannya, mereka memerlukan lahan yang subur dan air yang bersih. Dengan begitu, jika lahan pertanian semakin menyempit dan adanya kerusakan ekologi sebagai akibat dari praktik-praktik dominasi terhadap alam, maka perempuan akan kehilangan hak-hak tradisionalnya untuk mengolah tanah dan sumber-sumber pangan bagi kehidupan keluarganya.

Ekofeminisme lahir dari dua akar kata "ekologi" yang berasal dari bahasa Yunani "Oikos" , yakni "rumah" dan "logos" yang berarti ilmu, sehingga ekologi dapat dikatakan sebagai ilmu pengetahuan mengenai hubungan antara organisme dan lingkungan (Odum, 
1983). Selanjutnya dengan memadukan kata "ekologi" dengan "feminisme", dapat diartikan sebuah gerakan feminis yang lebih menekankan pada sebuah tujuan untuk melestarikan lingkungan atas sumber-sumber daya alam, khususnya untuk keberlangsungan di masa depan. Shiva dan Mies, menyatakan bahwa ekofeminisme mengacu pada sebuah keterkaitan dan intergritas dari setiap makhluk hidup dan gerakan ini diidentifikasikan sebagai gerakan perempuan (Shiva \& Maria, 2005). Gerakan ekofeminis dipercaya oleh King sebagai gerakan yang bertanggung jawab melawan bentuk-bentuk dualisme. Ekofeminisme menegaskan bahwa tidak ada perbedaan tingkat nilai antara manusia dan alam, seperti juga halnya tidak ada perbedaan antara laki-laki dan perempuan. Bagi kaum feminis, semua wujud di dalam alam memiliki nilai yang sama dan tidak mengotak-ngotakkan pada hierarki, seperti bangsa, warna kulit, dan jenis kelamin (King, 1994).

Ekofeminisme diperkenalkan di Jepang dan pada tahun 1980-an, dipicu oleh munculnya aksi-aksi yang menentang pencemaran air oleh penyakit Minamata sebagai dampak dari radiasi nuklir. Penyakit yang banyak menelan korban ini mulai menjadi perhatian dunia sejak Jepang menghadirkan pasien-pasien penderita Minamata pada Konfrensi Lingkungan sedunia yang diselengarakan di Sweden pada tahun 1972 (Kintou, 1994). Pada saat itu, berbagai gerakan kaum ekofeminisme di Jepang mulai menantang aksi-aksi yang berkaitan dengan kekerasan, dampak nuklir, dan pencemaran alam.

Selain di Jepang, gerakan perempuan untuk menyelamatkan alam dari eksploitasi masyarakat patriarki juga muncul di beberapa negara. Gerakan lokal Chipko Andolan di Pegunungan Himalaya, India melakukan protes terhadap perusakan lingkungan yang disebabkan oleh penebangan kayu yang dilakukan oleh para pengembang. Gerakan lokal yang terjadi pada tahun 1970 ini melakukan aksinya dengan memeluk pohon-pohon yang akan ditebang dengan menggunakan buldozer. Aksi yang berani sebagai upaya untuk menyelamatkan pepohonan ini, dapat dimaknai sebagai hubungan yang simbolik antara pohonpohon dengan kehidupan kaum perempuan. 


\subsection{Perempuan dan Alam}

Perempuan dan alam memiliki keterkaitan yang diasosiasikan dengan sifat-sifat perempuan, seperti mengandung, merawat, dan mengasuh. Asosiasi-asosiasi ini secara tidak langsung diakui oleh beberapa kaum feminis yang dapat dilihat melalui karya-karyanya. Mary Daly dan Susan Griffin memberikan perpektif baru berkenaan dengan keterkaitan perempuan dan alam. Pandangan Daly dan Griffin dalam Gyn/Ecology seperti yang dikutip oleh Cox menyatakan bahwa perempuan baik secara fisik, mental, dan juga spiritual didominasi oleh lakilaki. Dalam menghubungkan pencemaran yang dilakukan laki-laki terhadap alam dan perempuan, Daly memakai analogi dengan gin/ekologi (gin/ecology) yang meyakini bahwa ginekologi perempuan sebagai sesuatu yang membuka, mengembangkan jaringan, dan memberikan kehidupan. Sebaliknya, ginekologi laki-laki lebih dikhususkan pada reproduksi, sehingga laki-laki tidak mampu mewujudkan hidup ke dunia dan juga tidak mampu berkomunikasi dengan alam (Cox, 1998).

Berbeda dengan Daly, Griffin menganggap perempuan merupakan bagian dari alam. Perempuan adalah alam yang melihat alam, alam yang menangis, dan alam yang berbicara mengenai alam kepada alam, sehingga perempuan dianggap memiliki hubungan istimewa dengan alam. Pandangan Griffin ini tertuang dalam puisi berikut ini.

"He says that women speaks with nature. That she hears voice from under the earth. That wind blows in her ears and trees whisper to her. That the dead sing through her mouth and the cries of infants are clear to her. But for him dialogue is over. He says he is not part of the world, and that he was set on this world as a stranger. He sets himself apart from women and nature" (Cox, 1998, 284).

Keterkaitan perempuan dengan alam dikatakan oleh Sherry B.Ortner karena disebabkan oleh beberapa faktor. Faktor-faktor tersebut di antaranya adalah berkaitan dengan fisiologi perempuan yang terlibat dengan 'spesies kehidupan'. Selain itu, dilihat dari konteks domestik, perempuan adalah sosok yang berperan mengolah berbagai jenis tumbuhan dan binatang menjadi sandang, pangan, dan papan. Tidak hanya itu perempuan juga merupakan sosok yang menumbuhkan-kembangkan 'makhluk-makhluk kecil' yang perlahan-lahan diubah menjadi makhluk kultural (Tong, 1998). 
Adanya pandangan yang menganggap bahwa perempuan memiliki kedekatan dengan alam seperti pandangan para perempuan tersebut, melahirkan banyak bentuk pemikiran dalam ekofeminisme. Namun, dari beberapa aliran ekofeminisme itu, terdapat dua bentuk aliran pemikiran yang kerap diperbandingkan. Kedua aliran itu adalah ekofeminisme sosial (social ekofeminism) dan ekofeminisme kultural (cultural ecofeminism). Ekofeminisme sosial merupakan sebuah pemikiran dari salah satu aliran kaum ekofeminis yang menitikberatkan segala kegiatannya pada isu-isu ekologi. Sementara, ekofeminisme kultural lebih memfokuskan pada dimensi spiritual sebagai landasan pemikirannya.

\subsection{Ekofeminisme Kultural}

Ekofeminisme kultural merupakan gerakan ekofeminis yang menyasar pada kebudayaan perempuan dan spiritualisme yang mementingkan alam, sisi kejiwaan, dan roh manusia. Dimensi spiritual yang dimaksud oleh pandangan kaum ekofeminis kultural mengacu pada keberagaman kekuatan spiritual yang berbasis bumi dengan kecenderungan pada penyembahan terhadap para dewi. Konsep spiritual bumi dianggap sebagai gambaran bumi yang kudus (sacred) dan pemelihara yang diinterpretasikan sebagai 'ibu' yang dikenal dengan 'Gaia', berasal dari bahasa Yunani klasik yang mengacu pada nama Tuhan atau dewi yang disebut sebagai Goddess Mother Earth (Cox, 1998; Eisler, 1994). Masyarakat Yunani kuno percaya bahwa bumi adalah perwujudan Gaia atau dewa duci bumi yang 'memberi kehidupan' kepada semua yang hidup di dunia melalui sumber-sumber alamnya, seperti sungai dan buahbuahan.

Perwujudan Gaia (Goddess Mother Earth) dianggap oleh kaum ekofeminis kultural memiliki kedekatan dengan perempuan dibanding laki-laki. Hal ini karena sifat-sifat alam memiliki kesamaan dengan perempuan, yakni sama-sama memberikan dan memelihara kehidupan. Perempuan mengandung dan melahirkan anak, kemudian merawatnya hingga tumbuh menjadi dewasa. Sama halnya dengan perempuan, alam pun merupakan lahan 'untuk melahirkan' semua kehidupan dan 'merawat' semua makhluk yang hidup di atasnya melalui sumber-sumber alam, seperti sungai, laut, dan hutan. Sebaliknya, laki-laki memiliki sifat yang 
mendominasi, menguasai, dan mengeksploitasi tidak hanya kepada perempuan tetapi juga kepada alam.

Bentuk spiritual dalam ekofeminisme sebagai contohnya terlihat pada ritual masyarakat pagan yang melakukan penyembahan kepada dewi dengan melakukan praktik perdukunan atau yang dikenal dengan shamanisme. Praktik shamanisme ini masih tetap bertahan di antara masyarakat asli, seperti suku-suku yang ada di Amerika. Para feminis kultural tertarik pada praktik shamanisme karena dianggap memiliki kepercayaan terhadap spiritual yang berbasis bumi. Bagi kaum ekofeminis kultural, praktik shamanisme dipercaya sebagai cara hidup dalam keseimbangan di atas bumi, sehingga banyak kaum ekofeminis mengambil peran dalam praktik penyembahan terhadap para dewi, seperti Spertnak dan Starhawk.

Ekofeminisme kultural yang menekankan pada dimensi spiritual tersebut, memiliki tujuan mendasar sebagai bentuk alternatif dalam masalah-masalah sosial melalui kebudayaan perempuan. Konsep kebudayaan perempuan dalam hal ini, merupakan sebuah pandangan yang menempatkan perempuan pada posisi yang tinggi dan memberikan nilai terhadap femininitas dan alam. Kebudayaan perempuan cenderung merendahkan kebudayaan laki-laki dengan sistem patriarkinya dan sebaliknya membela dan memuja perasaan dan tubuh perempuan. Ekofeminisme kultural membandingkan antara kebudayaan laki-laki yang didasari oleh sistem patriarki yang rasional, sedangkan hubungan perempuan dengan alam lebih bersifat intuitif dan spiritual. Konsep hubungan itu secara keseluruhan menurut kaum ekofeminis kultural dapat dilihat secara historis, biologis, dan empiris. Hubungan ketiganya ini terlihat dalam berbagai bentuk kegiatan yang dapat mengidentifikasi perempuan dengan alam, seperti melalui pertunjukan, lagu, upacara, mitos, dan komunitas penyembuhan yang dilakukan oleh perempuan.

Berdasarkan uraian di atas, ekofeminisme kultural sebagai sebuah konsep dapat digunakan dalam menganalisis karya sastra. Dengan menggunakan perspektif ekofeminisme kultural, diharapkan dapat memberi gambaran mengenai kebudayaan perempuan dengan kualitas-kualitas femininnya, yang terlihat dalam teks novel $\mathrm{HWHI}$. 


\section{Metode Penelitian}

Penelitian ini menggunakan metode kualitatif dengan perspektif ekofeminisme kultural. Selanjutnya guna memperoleh sasaran pendeskripsian yang terarah, close-reading sebagai salah satu metode pembacaan teks sastra baik itu puisi maupun novel digunakan untuk pembacaan mendalam terhadap novel Hana wo Hakobu Imouto. Close reading dinyatakan oleh McCall (2017) bahwa "close-reading is a method of reading for messege, it become employed as an approach to textual interpretation that lead to quantifiable knowledge". Dengan kata lain bahwa metode close reading merupakan proses penginterpretasian teks melalui proses pembacaan yang mendalam untuk mendapatkan pesan yang terkandung dalam suatu teks.

Setelah menggunakan metode close reading, dilakukan analisis berdasarkan perspektif ekofeminis kultural. Pemilihan ekofeminisme kultural sebagai pijakan teori dalam menganalisis novel $H w H I$, didasari adanya asumsi penulis yang melihat adanya simbol-simbol femininitas sebagai bentuk kebudayaan perempuan melalui pemerian alam secara metaforis.

\section{HASIL DAN PEMBAHASAN}

\subsection{Hubungan Tokoh-Tokoh Perempuan dengan Alam dalam Novel HwHI}

$H w H I$ adalah novel yang menceritakan perjuangan seorang tokoh perempuan yang berupaya menyelamatkan kakak laki-lakinya yang terancam hukuman mati karena dianggap sebagai pengedar narkoba. Cerita dalam novel ini dinarasikan melalui sudut pandang dua orang tokoh yang memiliki hubungan adik kakak, yakni Kaoru Nishijima dan Tetsuro Nishijima. Selain tokoh Kaoru, dalam novel ini pun muncul beberapa tokoh perempuan yang memiliki peran penting dalam kehidupan Tetsuro, yakni tokoh Nguyen Ti An dan Inge Bruge. Peran tokoh-tokoh perempuan ini selain melahirkan berbagai konflik yang berpengaruh terhadap kehidupan tokoh Tetsuro, juga memperlihatkan adanya interkasi khusus yang terjalin antara ketiga tokoh perempuan ini dengan latar tempat yang muncul dalam cerita.

\section{Tokoh Kaoru Nishijima}

Kaoru Nishijima merupakan tokoh yang menonjol dan juga bertindak sebagai narator dalam novel $\mathrm{HwHI}$. Kaoru adalah adik perempuan Tetsuro, yang banyak menghabiskan waktunya di luar negeri. Pada tahun 1980, la meninggalkan Jepang dan memulai tinggal di Paris, 
Prancis sebagai mahasiswa asing yang belajar bahasa Prancis di Universitas Sorbonne. Namun, meskipun ia menetap lama di Paris, ia tidak berhasil menyelesaikan kuliahnya karena ia lebih memilih bekerja sebagai interpreter bagi orang-orang Jepang yang datang ke Prancis dan beberapa negara Eropa lainnya. la sering pulang pergi ke Jepang untuk urusan pekerjaan dan saat ia pulang ke Jepang pada awal tahun baru, ia mendapat kabar bahwa kakaknya tertangkap di Bali karena kasus narkoba. Untuk menyelamatkan kakaknya, ia pun berangkat ke Indonesia dengan harapan dapat menolong kakaknya.

Penggambaran tokoh Kaoru dalam novel ini terkait erat dengan dua latar tempat, yakni kota Paris dan Bali yang digambarkan secara dominan. Dalam teks cerita dikemukakan pandangan tokoh Kaoru terhadap kondisi kota Paris yang secara fisik diwakili oleh dua buah pulau yang ada di Prancis, yaitu Saint Louis dan pulau Cite yang dianalogikan sebagai dua buah perahu yang terapung di sungai Seine. Kaoru menganalogikan kedua pulau ini sebagai adik lakilaki yang berjalan di belakang mengikuti kakaknya (Ikezawa, 2003, p.9). Bagi Kaoru, kondisi kedua pulau ini, secara tidak langsung mengingatkan Kaoru pada kakak laki-lakinya yang bernama Tetsuro Nishijima.

Dalam penggambaran latar kota Paris, sungai merupakan unsur alam yang dominan digambarkan dalam cerita. Dari penuturan tokoh Kaoru, kondisi sungai di Prancis secara fisik digambarkan sebagai sungai yang besar, jernih, dan dikelilingi oleh pepohonan. Selain itu, secara spiritual latar sungai juga digambarkan sebagai tempat pembaptisan Kaoru yang dilakukan secara paksa oleh pendeta Makino. Dengan perasaan takut, Kaoru masuk ke dalam sungai menuju ke arah Makino yang sudah lebih dulu berada di tengah-tengah sungai. Ketika Kaoru tiba di sana, tanpa diduga Makino menenggelamkan kepalanya, sehingga ia menduga Makino bermaksud ingin membunuhnya. Namun, di tengah ketakutannya tenggelam di sungai, secara tiba-tiba perasaannya menjadi tenang. la merasakan tubuhnya yang terbenam ke dalam air sungai memberi pengalaman spiritual yang berbeda. la merasakan semangat yang tidak ada kaitannya dengan agama Katolik, sebuah kekuatan yang ia peroleh saat ia membenamkan tubuhnya ke dalam air sungai di malam hari. Berikut ini adalah kutipan yang menggambarkan perasaan Kaoru saat ia membenamkan seluruh tubuhnya ke dalam air sungai. 
信仰を受け入れるのではなくて、これからキリスト教徒として生きるのではなく、 私の魂を水で洗うという彼の意思を受け入れる。この川の水を、この夜の闇を、 受け入れる。そう思った時、ここで死奴じゃないとわかった時、わたしは生き る喜びに満たされた。まるで恩龍のようでした。

Ini bukan berarti aku mempercayai iman, dan bukan berarti mulai kini aku hidup sebagai pemeluk agama Katolik, tapi aku menerima pendapat pendeta Makino bahwa jiwaku dibasuh dengan air. Aku menerima semangat dari gelapnya malam dan air sungai ini. Ketika berpikir seperti itu, aku menyadari bahwa aku tidak akan mati di sini. Hatiku kini dipenuhi dengan kegembiraan untuk hidup. Ini seolah-olah adalah anugerah (Ikezawa, 2003, p.33).

Selanjutnya latar pulau Bali dalam novel $H w H I$ digambarkan sebagai tempat bertemunya Kaoru dengan Tetsuro. Dari sekian banyak latar tempat yang muncul dalam teks novel, pulau Bali menjadi latar yang paling dominan dan juga menjadi tempat lahirnya konflik dan penyelesaian masalah yang dialami oleh tokoh Kaoru dan Tetsuro. Pulau Bali digambarkan sebagai pulau yang unik dan istimewa. Hai ini karena di antara sebagian besar wilayah Indonesia yang mayoritas penduduknya beragama Islam, di pulau Bali justru mayoritas penduduknya beragama Hindu. Keistimewaan inilah yang diceritakan oleh tokoh bernama Kondra, mewakili orang Bali yang berprofesi sebagai penerjemah bahasa (Ikezawa, 2003, p.221).

Kebudayaan Bali mendapat pengaruh kuat dari kebudayaan Hindu India dan kebudayaan Jawa. Bali merupakan daerah yang berhasil ditaklukkan kerajaan Majapahit dari Jawa yang kemudian mendirikan kraton di Gelgel yang berada di bagian Tenggara pulau. Menurut sejarah, awal terbentuknya Bali sebagai pusat agama Hindu, disebabkan oleh gelombang imigrasi besar-besaran ke Bali, setelah kerajaan Hindu Majapahit jatuh pada abad ke-16. Para bangsawan, sastrawan, pendeta, dan seniman yang menghindari desakan agama Islam di Jawa, memilih untuk menyingkir ke Bali sebagai upaya mempertahankan agama Hindu yang dianutnya (Picard, 2006, p.22).

Latar Bali digambarkan sarat dengan berbagai ritual dan upacara keagamaan. Masyarakat Bali dikenal sebagai masyarakat pencinta karya seni. Berbagai pertunjukkan, seperti musik, tarian, dan sandiwara yang sering diadakan di alam terbuka menjadi bagian yang tidak dapat dipisahkan dalam kehidupan masyarakatnya. Kondisi ini menjadi bentuk interaksi manusia dengan alam, yang meliputi tanah, udara, air, dan sistem energi yang mendukung 
siklus kehidupan mereka sebagai manusia, dan menurut pandangan ekofeminis kultural dianggap sebagai gaya hidup yang peduli dengan alam sekitar.

Penggambaran latar Bali dalam novel ini secara keseluruhan memperlihatkan berbagai unsur alam, namun di antara yang paling menonjol adalah unsur alam berupa laut yang dipertentangkan dengan gunung. Kedua unsur alam ini, menjadi bagian penting dalam melukiskan spiritualitas pulau Bali yang menjadi daya tarik bagi tokoh-tokoh, seperti Kaoru dan Tetsuro. Dalam kosmologi Bali, gunung dianggap sebagai 'dunia atas' (kaja). Masyarakat Bali percaya gunung, terutama Gunung Agung sebagai tempat suci yang menjadi sumber kesuburan dan kehidupan serta tempat bersemayamnya para dewa dan leluhur-leluhur yang didewakan. Sementara laut dianggap sebagai 'dunia bawah' (kelod) dan menjadi tempat bersemayamnya dewi kematian. Besarnya kepercayaan masyarakat Bali terhadap hal itu, dapat dilihat dari jenis pura yang dibangun di kedua lokasi itu. Pura desa dan pura puseh dibangun menghadap gunung, sedangkan pura dalam menghadap laut. Pura desa berfungsi sebagai tempat rapat dewan desa yang terkait dengan ritual-ritual kesuburan. Pura puseh sebagai tempat untuk melakukan upacara penghormatan terhadap para leluhur, dan pura dalem didirikan untuk menyembah dewi kematian yang dikenal dengan Dewi Durga (Nakamura, 2001, p.15).

Dalam novel $H w H I$, unsur-unsur alam tersebut, terutama air digambarkan memiliki hubungan khusus dengan tokoh Kaoru. Hal ini terlihat ketika Kaoru mengunjungi pura yang ada di Uluwatu untuk menenangkan hatinya agar ia dapat melupakan tindakan para aparat yang merendahkannya. Saat Kaoru berdiri memandang laut dari kejauhan, ia mendengar suara laut seakan-akan memanggilnya.

海の指はわたしの深いところに届きます。自分の心の動きが遅くなって、大きく ゆっくりと舞うような波のリズムに㭔応して、静かに穏やかになっていくのがわ かりました。

Tangan laut menjangkau hingga ke tempat terdalam yang ada dalam diriku. Gerakan hati menjadi lambat dan ombak besar seakan menari dengan irama yang bersahutan. Maka aku pun mengerti mengapa perasaanku menjadi tenang (Ikezawa, 2003, p.349).

もうに歩進んだところでわたしはゆっくり水の中に座り込みました。ひんやりと した衣服の中に入ってきて、全身の皮膚が濡れる。皮膚之衣服の間を水が満たし ている。水がわたしを抱いている。身を任している。いい気持ちです。おたしは 頭まですっかり水に入れます。 
Setelah maju dua langkah, perlahan-lahan aku duduk dan membenamkan diri ke dalam air. Air mulai membasahi baju dan seluruh kulitku, memenuhi ruang di antara baju dan kulitku. Air sedang memelukku. Aku pasrahkan diri dan perasaanku pun menjadi tenang. Aku membenamkan seluruh tubuhku ke dalam air hingga ke kepala (Ikezawa, 2003, p.353).

Pembenaman tubuh Kaoru ke dalam air laut seperti pada kutipan di atas, secara tersirat dari sudut pandang feminis kultural sebagai bentuk pemujaan terhadap Dewi Bumi (Goddess Mother Earth). Hal ini berdasar pada kosmologi Bali yang mempercayai laut sebagai tempat bersemanyamnya Dewi Durga yang dikenal sebagai dewi kematian. Masyarakat Bali, untuk menghindari kemarahan Dewi Durga, mereka membangun pura dalem yang berdiri terpisah dari desa dan menghadap laut.

\section{Tokoh Nguyen Ti An}

Nguyen Ti An adalah seorang perempuan Vietnam yang juga berperan dalam kehidupan Tetsuro. la memiliki anak bernama Tanh dan membesarkannya seorang diri karena suaminya gugur dalam perang Kamboja. Pertemuan Nguyen Ti An dengan Tetsuro terjadi ketika Tanh mengajak Tetsuro ke rumah dan memperkenalkannya kepada Nguyen Ti An. Pada saat itu, Tetsuro sedang melakukan perjalanan ke sebuah desa di Vietnam untuk mencari sesuatu yang menarik sebagai objek lukisannya. Selama berada di Vietnam, Tetsuro menginap di rumah Nguyen Ti An, dan sejak saat itu terjalin hubungan khusus di antara mereka berdua. Sama halnya dengan Kaoru, penarasian tokoh Nguyen Ti An juga banyak dikaitkan dengan kondisi latar Vietnam beserta unsur alam yang ada di dalamnya.

Dalam cerita ini, pemerian latar Vietnam secara fisik didominasi oleh latar pesawahan, gunung, dan hutan. Unsur alam, seperti gunung, hutan, dan terutama sawah menjadi unsur

yang paling ditonjolkan. Tampaknya bagi masyarakat Vietnam, sawah tidak dapat dipisahkan dari kehidupan mereka sehari-hari. Sawah memiliki peran penting bagi Nguyen Ti An sebagai tempat untuk menyandarkan hidup.

納屋の中は米や、農具の鉄や木、土、いろいろなものの、混じったいい包いがし た。

Di dalam gudang, tercium bau yang sedap campuran dari berbagai macam barang, ada beras, perkakas pertanian, kayu, dan tanah (Ikezawa, 2003, p.259). 
Bagi Nguyen Ti An, sawah bagian penting dalam kehidupannya. Tanpa sawah ia tidak mungkin dapat menghasilkan beras untuk menghidupi dirinya dan seorang anak. Terkait dengan peran sawah dalam kehidupan Nguyen Ti An, dilihat dari sudut pandang ekofeminis kultural, sawah merupakan representasi dari 'Gaia' atau 'ibu bumi' yang 'melahirkan' dan 'merawat' semua kehidupan serta 'memberi makan' kepada semua makhluk yang ada di bumi melalui sumber-sumber alamnya. Benih padi yang disemaikan di sawah, tumbuh berkembang menghasilkan padi yang berkualitas sebagai salah satu sumber alam yang digunakan untuk kelangsungan hidup manusia.

\section{Tokoh Inge Bruge}

Tokoh Inge Bruge dalam novel ini ditampilkan sebagai oposisi biner dari kedua tokoh perempuan sebelumnya, yakni Kaoru Nishijima dan Nguyen Ti An. Kedua tokoh perempuan ini sama-sama berasal dari Asia, sedangkan Inge Bruge adalah seorang perempuan Eropa berkebangsaan Jerman. Tokoh ini digambarkan memiliki ketertarikan yang besar terhadap alam. Hanya saja ketertarikannya terhadap alam dirasa aneh, karena kerap membandingkan alam yang kekal dengan kehidupan manusia yang fana.

\section{世界はいつになっても死なない。それを見る人閒は死ぬ。}

Dunia itu sampai kapanpun tak akan mati. Manusia yang melihat dunia itulah yang akan mati (HwHI, p. 209).

Tokoh Inge Bruge sama seperti Kaoru dan Nguyen Ti An keduanya berperan dalam kehidupan Tetsuro. Hanya saja, Inge Bruge berfungsi sebagai tokoh yang menciptakan konflik bagi tokoh Tetsuro, karena tokoh ini yang memperkenalkan heroin kepada Tetsuro. Pertemuan Inge Bruge dengan Tetsuro terjadi di Thailand, sehingga narasi keduanya banyak melukiskan latar Thailand dengan menekankan pada penggambaran hujan sebagai unsur alam yang dominan. Hujan dalam novel ini digambarkan sebagai ciri khas dari negara Thailand.

\footnotetext{
あの暑い、水蒸気に満ちた、恵の国、いつも雨にめれた直後のような みずみず しい色の国。僧たちが柿色の衣ひらかめかして歩く国。

Negara panas dengan uap air yang melimpah. Negara yang selalu tampak segar seakanakan baru dibasahi hujan. Negara para biksu yang berjalan dengan jubah berwarna kesemek (kuning safron) (Ikezawa, 2003, p.197).
} 
翌日は雨になった世界全体を洗って、人間たちのあらゆる罪を浄めるような雨が 朝からはいぜんを降っている。

Keesokan harinya hujan turun mencuci dunia secara menyeluruh, hujan yang turun lebat dari pagi seolah-olah membersihkan seluruh dosa (Ikezawa, 2003, p.203).

Thailand sebagai salah satu negara tropis di Asia memiliki curah hujan yang tinggi. Hujan yang selalu turun deras seperti tak pernah berhenti membasahi bumi merupakan sifat hujan yang ditampilkan untuk melukiskan keadaan Thailand. Dalam cerita ini, hujan tidak hanya dilukiskan secara fisik, namun juga secara spiritual. Dalam kutipan di atas terlihat bahwa derasnya hujan yang turun dianalogikan sebagai media untuk mencuci dunia dan juga seluruh dosa-dosa manusia. Gambaran hujan secara spiritual juga semakin menonjol dengan digambarkannya latar fisik Thailand sebagai negara para biksu yang memakai jubah berwarna kuning safron sebagai ciri khas negara tersebut yang mayoritas penduduknya beragama Buddha.

\subsection{Pemerian Femininitas pada Alam}

Unsur alam yang muncul dalam novel $H w H I$ seperti yang telah dikemukakan sebelumnya memiliki hubungan khusus dengan ketiga tokoh perempuan, yakni Kaoru Nishijima, Nguyen Ti An, dan Inge Bruge. Hubungan yang terjalin antara perempuan dengan alam ini memperlihatkan adanya kesamaan karakter di antara keduanya. Secara metaforis unsur-unsur alam yang muncul dalam novel ini diasosiasikan dengan simbol-simbol femininitas. Dari sekian banyak unsur alam yang muncul, hujan merupakan unsur alam yang dominan dan merepresentasikan simbol-simbol femininitas.

Unsur air dapat ditemukan hampir di semua latar tempat yang ada dalam teks novel, seperti di Prancis didominasi oleh sungai, Thailand oleh hujan, dan Bali oleh laut. Dalam kehidupan sehari-hari air adalah salah satu unsur alam yang berperan besar dalam kehidupan manusia dan makhluk hidup lainnya. Tidak hanya itu, air juga merupakan unsur penting dalam proses pembentukan tubuh manusia. Emoto menyatakan bahwa sel telur yang dibuahi sembilan puluh enam persennya adalah air dan setelah lahir, delapan puluh persen tubuh seorang bayi adalah air. Kemudian semakin berkembang tubuh manusia, presentasi air 
berkurang dan menetap hingga batas tujuh puluh persen ketika manusia mencapai usia dewasa (Emoto, 2006, p.17).

Pemerian air sebagai simbol yang mengacu pada femininitas dapat terlihat pada saat interaksi Kaoru dengan cara membenamkan seluruh tubuhnya ke dalam air laut di sebuah tempat yang bernama Uluwatu. Proses interaksi itu dapat dianalogikan sebagai bentuk spesies yang hidup dalam 'lautan' rahim seorang ibu. Sementara, Kaoru yang membenamkan tubuhnya ke dalam air, diumpamakan sebagai fetus yang berkembang dan berenang dalam 'lautan' rahim seorang ibu. Menurut Emoto (2006, p.18), cairan amnion dalam kandungan ibu mempunyai sifat yang mirip dengan komponen yang ada pada air laut. Selanjutnya fetus menunggu waktu kelahirannya dalam 'lautan' di rahim ibu dengan bernafas melalui plasenta.

Interaksi Kaoru dengan air laut ini dalam sudut pandang ekofeminis kultural menyiratkan simbol-simbol femininitas yang dilambangkan dengan 'ibu yang mengandung' dan 'menjaga kehidupan' dalam 'rahim' melalui pengasosiasian antara 'lautan' dan Kaoru' yang membenamkan dirinya ke dalam air laut. Unsur air juga digambarkan memiliki keterkaitan dengan perempuan melalui komunikasi secara metafor melalui pembenaman tubuh Kaoru ke dalam laut. Melalui interkoneksi di antara keduanya, air dapat direpresentasikan sebagai unsur yang berperan penting dalam proses revitalisasi diri Kaoru yang melahirkan spirit dan kepercayaan dalam menghadapi opresi dari masyarakat patriarki.

Selanjutnya unsur 'tanah' direpresentasikan sebagai simbol 'Ibu bumi' yang dikenal sebagai 'Gaia' melalui penggambaran latar sawah, hutan yang ada di Vietnam dan gunung yang berada di Bali. Sawah dalam novel HwHI menjadi sandaran bagi kehidupan tokoh Nguyen Ti An. Dalam kehidupan sehari-harinya, ia tidak dapat dilepaskan dengan sawah karena sawah telah memberikan kehidupan melalui padi yang ia panen setiap tahunnya. Dari pemerian unsur air sebagai 'rahim ibu' dan unsur tanah sebagai 'ibu bumi' dapat disimpulkan bahwa kedua unsur alam tersebut merepresentasikan simbol femininitas perempuan yang melindungi, memberi hidup kepada semua makhluk di atas muka bumi ini. 


\section{Simpulan}

Dari hasil pembahasan tokoh-tokoh perempuan yang muncul dalam novel $H w H I$ dengan menggunakan sudut pandang ekofeminisme kultural, terlihat bahwa ada hubungan khusus yang terjalin antara perempuan dengan alam secara spiritual. Hubungan di antara mereka ini dilihat melalui sudut pandang ekofeminisme dikaitkan dengan kepercayaan terhadap mitos mengenai kesucian bumi yang dianalogikan dengan sosok seorang 'ibu' yang merawat, melindungi, dan memberi kehidupan. Sosok 'ibu' ini dikenal sebagai 'Gaia' (Goddess mother earth).

Konsep 'gaia' (Goddess mother earth) ini dalam novel HwHI direpresentasikan melalui unsur-unsur alam yang muncul di latar cerita. Dari beberapa unsur alam yang muncul dalam cerita, seperti sungai, hujan, sawah, dan laut, dapat disimpulkan bahwa air merupakan unsur alam yang dominan, meskipun dilukiskan dengan objek yang berbeda-beda. Dalam novel ini, air selain sebagai simbol penghapus dosa, air juga merepresentasikan simbol femininitas. Sifat air dipersonifikasikan sebagai sesuatu yang hidup, memiliki jiwa dan bergerak mengikuti irama adalah bentuk kehidupan yang dirasakan oleh Kaoru. Melalui pembenaman tubuh Kaoru ke dalam air laut, memperlihatkan sebuah analogi bahwa laut adalah 'rahim ibu' yang mengandung, melindungi, dan memberi kehidupan kepada makhluk hidup. Selain laut, unsur alam yang lainnya adalah tanah yang direpresentasikan melalui sawah. Pemerian sawah dalam novel ini diasosiasikan sebagai 'ibu bumi' atau disebut dengan 'gaia' (Goddess mother earth). Sawah yang menjadi representasi dari Goddess mother earth, memberi 'kehidupan' kepada makhluk hidup melalui padi-padian, buah-buahan, dan sayuran yang keluar dari perut bumi.

Pemerian alam melalui unsur alam air dan tanah sebagai sesuatu yang merawat, melindungi, dan memberi kehidupan dapat dikatakan mewakili sifat-sifat perempuan. Pemerian unsur-unsur alam dengan simbol-simbol femininitas tersebut, secara tidak langsung menunjukkan sebuah gagasan kritis terhadap budaya patriarkis dengan pengagungan terhadap budaya 'perempuan' yang selama ini dianggap inferior. 


\section{Daftar Pustaka}

Ahmadi, A. (2017). Feminis, Ekofeminisme, dan Cerpen Indonesia. Totobuang, 5(1), 163-174.

Cox, C. (1998). Ecofeminism. In G. Kirkup \& L. S. Keller (Eds.), Inventing Women: Science, Technology, and Gender (pp. 284-291). United Kingdom: Polity Press.

Eisler, R. (1994). Gaia no Dentou to Kyousei no Mirai. Tokyo: Gakuseishourin.

Ikezawa, N. (2003). Hana wo Hakobu Imouto. Tokyo: Bunshun Bunsho.

King, Y. (1994). Kizu wo lyasu. In I. Diamond \& G. F. Orenstain (Eds.), Sekai wo Orinaosu: Ekofeminizumu no Kaika (pp. 184-194). Tokyo: Gakugeishorin.

Kintou, K. (1994). Nihon no Ekofeminizu no Kanousei. In I. Diamond \& G. F. Orenstain (Eds.), Sekai wo Orinaosu: Ekofeminizumu no Kaika (pp. 452-453). Tokyo: Gakuseishorin.

Lestari, R. (2009). Citra Wanita dalam Karya Sastra: Tinjauan Kritik Sastra Ekofeminis terhadap Kumpulan Cerpen Jiwaku Adalah Wanita Karya Azimah Rahayu. Universitas Gadjah Mada.

McCall, J. (2017). Close reading: the theory which is not one. Retrieved October 1, 2018, from http://tigerprints.clemson.edu/emc/vol12/iss1/7

Nakamura, Y. (2001). Majo randa Kou. Tokyo: Iwanami Shouten.

Numano, M. (2005). Gendai Nihon Shosetsu no Atarashii Keikou 25 November 2005. Jakarta: Universitas Indonesia.

Odum, E. (1983). Basic Ecology: Introduction The Scope of Ecology. San Fransisco: Saunders College Publishing.

Picard, M. (2006). Bali: Pariwisata Budaya dan Budaya Pariwisata Jakarta: Gramedia. Jakarta: Gramedia.

Shiva, V., \& Maria, M. (2005). Ekofeminis: Perpektif Gerakan Perempuan dan Lingkungan. Yogyakarta: Ire Press.

Tong, R. (1998). Feminist Thought: Pengantar Paling Komprehensif Kepada Arus Utama Pemikiran Feminis. Bandung: Jalasutra. 